\title{
Community Understanding of Superannuation
}

\section{Diana Beal and Sarath Delpachitra}

$\mathrm{S}$ uperannuation has had a chequered history in Australia. From its beginning early in the mercantile history of Australia, when banks used their employee provident funds as 'golden handcuffs' to keep employees loyal and honest, until the 1980s, superannuation remained essentially the preserve of senior whitecollar male employees (McKeown, 2003). Along the way, some interesting abuses were perpetrated by employers for personal gain. Such abuses included 'cherry-picker' funds where employers of short-term employees set up selfmanaged funds, contributed funds for employees including themselves and claimed tax deductions to reduce taxable incomes and tax liabilities. However, under the terms of the trust deeds, only long-term employees could benefit and thus only the employers qualified. The employers then paid the majority, if not all, of the invested funds to themselves (McKeown, 2003).

Things began to change for the better in the second half of the 1980s and early 1990s. Two forces of change stand out. First, the union movement and the Federal Government agreed to a series of Prices and Incomes Accords which were designed to increase rewards to employees but to restrain inflationary pressures. In Accord Mark II, wage rises were traded for superannuation contributions. Employers then objected to subsequent Industrial Commission rulings and, on appeal, the High Court of Australia in 1986 (160 CLR 341) decided that superannuation would be regarded henceforth as a condition of employment. Second, in order to try to overcome a looming budgetary problem caused by the ageing of the population, the Federal Minister for Social Security in 1989 released a retirement incomes policy which had three pillars - compulsory superannuation contributions, voluntary superannuation contributions, and the age pension as income support or top-up for those with insufficient other income in retirement (Howe, 1989). By that time, the age pension had been in place for nearly a century, but compulsory superannuation contributions made by employers in addition to employees' salaries and wages for nearly all employees were new. The legislation, the Superannuation Guarantee Charge Act 1992, made the compulsory contribution 3 per cent in the first instance, rising to 9 per cent by July 2002.

In the twelve years since the introduction of compulsory superannuation the government has, on several occasions, proposed legislation to require employers to offer their employees a choice of funds to which their contributions would be made. Even though this legislation has not been passed, the industry has reacted to the proposals by introducing several investment choices for most fund members. The upshot of these proposals, even though they were made with the

Diana Beal is Director, and Sarath Delpachitra is a Research Fellow, in the Centre for Australian Financial Institutions at the University of Southern Queensland. 
best of intentions to allow fund members to align their superannuation investments with their personal risk tolerances, has been to put pressure on members to learn more about superannuation and to take some responsibility for decisions which will impact significantly on their eventual retirement incomes. As Assistant Treasurer, Helen Coonan, (2002:19) noted: 'measures such as choice ... give greater responsibility to the individual'.

The Assistant Treasurer's allusion to choice highlights the philosophical environment within which this issue resides. On one hand, economists argue that individuals are the best judges of their own welfare and thus make the best decisions regarding their own actions. In this context, individuals must choose between current consumption with its instant gratification and deferred consumption with its delayed gratification which eventually is enjoyed during their retirement years. Many individuals find it difficult to defer gratification, even though they are aware that, unless they do so, they are sentencing themselves to lifestyles significantly less comfortable than they enjoy during their years of employment. On the other side of the argument, the government is aware that individuals are generally not deferring sufficient consumption to allow adequate saving for their retirements. To try to improve retirement savings and to relieve future pressure on public-sector budgets, policy makers have imposed this compulsory savings strategy on the community in the form of the superannuation system.

The issue of choice, and especially informed choice, has been widely acknowledged as vitally important to the success of the superannuation policy. Indeed, the Senate convened a Select Committee to investigate and report on the choice of superannuation funds in 1997-98 (Senate, 1998). The Committee noted two requirements of informed choice: the education of consumers [investors]; and employers, and adequate disclosure of funds information (Senate 1998:Part 5.1). According to the Committee (Senate,1998:Parts 5.9-5.10), informed choice will promote competition and efficiencies among funds and a culture of active interest among consumers. The importance of informed consumers is highlighted by the Australian Bankers' Association's evidence to the Committee that 'with compulsion, people do not feel in control. There is still a negative attitude to super as an investment. ... There are low levels of literacy' (Senate, 1998:Part 5.11).

Some may argue that individuals do not need to be familiar with the details of the superannuation framework, as they may employ advisers. Certainly, people may purchase advice, but confident knowledgeable people then make their own decisions after considering the advice received, their own knowledge and their understanding of their own wants and goals, both stated and tacit. People without such knowledge of the system are condemned to second-best solutions as they are unable to evaluate the advice received.

The research reported in this paper investigates the level of knowledge of individual fund members about the superannuation system. In addition, the investigation was designed to throw some light on members' perceptions of their own knowledge as well as their knowledge as revealed by their answers to the 
technical questions posed. To this end, the next section provides a brief review of the literature, followed by an outline of the data collection and analytical methodology. The penultimate section presents the findings and while the final sections provides discussion and conclusions.

\section{Literature Review}

To the best of the authors' knowledge, there have been no academic published papers examining Australians' understanding of their superannuation system, even though detailed knowledge is vital to most employees' achievement of their individual informed choice and retirement objectives, to the achievement of efficiencies in the superannuation industry and to the achievement of effective policy on the part of the government.

There has, however, been limited relevant research conducted overseas, most notably in the USA and Canada. An early study in the USA by Mitchell (1988) used data from the 1983 Survey of Consumer Finances together with surveys of individuals to examine the quality of workers' knowledge of their pension plans. She found unionised, higher-income, better-educated and senior staff were better informed than others. In addition, she found demographic differences in that Americans of European racial origin were better informed, as were women, about several facets of their pension plans.

Gustman and Steinmeier (1999) compared descriptions of their pension plans given by respondents to the 1992 US Health and Retirement Study (HRS) with data given by their respective employers. They found that only half of the respondents could correctly identify the type of pension plan they participated in (that is, defined benefit or defined contribution). Fewer than half could identify correctly (within one year) their eligibility dates for early or normal retirement. The authors noted that their findings raised considerable doubt about how well respondents understood the more complex areas of pension and social security rules.

Gustman and Steinmeier (2001) built on their earlier work using data from the HRS to report that imprecision, wrong information and lack of information about retirement benefits is the norm. They found women, contrary to Mitchell's (1988) findings, and racial minorities were less well informed. In addition, they found people that planned were 'modestly' better informed than non-planners.

Further relevant retirement-policy research was reported by Chan and Stevens (2003). Chan and Stevens were perplexed that retirement policy incentives appeared to be effective, yet both anecdotal evidence and academic research pointed to the population not knowing much about their pension schemes. They found uninformed people showed no response to actual retirement incentives, while informed people reacted much more strongly than previously thought. As virtually all recent empirical research had been based on administrative data which effectively averages responses, their findings have important implications for retirement policy formation and policy assessment. In addition, they noted the generalised finding that lack of knowledge of policy incentives by individuals, 
and the paucity of education programs contribute to reduced responsiveness to economic policies and made the policies less effective.

Luchak and Gunderson (2000) reported a 1988 survey of 529 employees of a large unionised public utility in Ontario, Canada. They found the level of pensionplan knowledge was low among all employees on average, but 'quite high' among those for whom the information mattered most for decision-making. These included older workers, higher-skilled and higher-paid workers, workers likely to retire early due to ill-health and workers who facing higher losses of pension entitlements if they quit or were sacked.

Focusing more closely on the Australian superannuation scene, the relevant literature is sparse. Stimulated by the failure of the proposed 'choice of fund for members' legislation, which was mentioned in the introduction to this paper, Brown, Gallery and Gallery (2002) developed a framework to examine the endogenous and exogenous constraints affecting the achievement of informed choice by superannuation fund members. They argued that a genuine choice paradigm should provide options for members to achieve either active or passive (default) choice. Further, they argued, in agreement with Senate (1998), that education programs and standardised disclosure by funds managers are critical for successful active management by members of their personal superannuation savings. Moreover, to cater for individuals wishing to select a passive management style, the authors argued that a government-managed default fund could protect the savings of vulnerable members much more effectively than the current arrangements.

The Senate (1998) Committee heard evidence from Coopers and Lybrand on the efficacy of focussed education programs. Although Telstra offered investment choice to its superannuation fund members in 1997, fewer than two per cent of more than 70,000 members elected to exercise a different choice from the trustees' default selections. In contrast, the Optus fund offered an 'intensive education campaign' and 75-80 percent of its superannuation fund members subsequently exercised investment choice (Senate,1998:Part 5.22). The Committee concluded that 'well designed and implemented communication and education campaigns are effective change agents' (Senate,1998:Part 5.23).

Drew and Stanford (2002) examined the current institutional arrangements for contributions which stem from the superannuation guarantee charge and award-mandated superannuation. Employees cannot currently choose where to place these contributions as the choice of fund is a decision made elsewhere. The authors found that the failed government legislation (referred to in the introduction to this paper) was too prescriptive, and argued that unlimited choice is the preferred policy for members. Gallery and Gallery (2003) argued that a better disclosure and reporting regime is required in the current context of narrow regulatory focus to enable informed members to make better choices.

Recent research conducted by ANOP Research Services for the Association of Superannuation Funds of Australia (ASFA) investigated perceptions and attitudes to superannuation, using a national survey of 706 people in the workforce aged 25-64 years. In a section reporting respondents' perceived knowledge of 
superannuation, seven per cent of respondents thought they were very well informed and 37 per cent thought they were quite well informed, thus making 44 per cent who were at least quite well informed. Another 48 per cent thought they were not very well informed and a further eight per cent were not at all informed or could not answer the question. Those more likely not to feel informed were the less skilled, lower income, women and part-time workers (ASFA, 2002:17-18). The question posed by these findings is: what does 'very well' or 'quite well informed' mean in practical terms?

In summary, while the relatively small Australian superannuation literature has been chiefly concerned with the adequacy of savings and superannuation contributions, funds returns, asset selection and funds safety, one policy issue which continues to be controversial is the matter of choice. Stemming from that issue is the concomitant concern with members' levels of superannuation knowledge. Many papers either directly or indirectly have pointed to the need for further education of the community. This research was designed to inform the debate about the deficits in community knowledge and where educational activity would assist.

\section{Research Method}

This section explains the way in which the data were collected, describes the characteristics of the sample, and discusses our approach to analysing the data.

\section{Data Collection}

The data for this analysis were collected by survey. A survey instrument was designed to include 18 technical questions about superannuation and retirement incomes, six standard demographic questions and one question which asked respondents to rate their own perceptions of their personal levels of superannuation knowledge.

Any test of the apparent knowledge of the Australian community about superannuation could be easily biased by the difficulty of the questions asked. In order to try to overcome this problem in the design of the survey 'test', a threestage process was followed to develop the final questionnaire. First, the member of the research team who teaches financial planning courses considered the question of just what constitutes basic knowledge of the superannuation system. A number of possible multiple-choice questions were devised. Second, the Commonwealth Government publication, A Brief Guide to Superannuation, was examined and it was ascertained that the answers to most questions were included in the guide. Only two questions of the 18 technical questions asked called for knowledge outside that contained in this brochure. These two questions called for a basic knowledge of the effect of the compounding of periodic returns and for current knowledge of the payment rate for the Commonwealth age pension. Finally, the draft questionnaire was pilot-tested among university colleagues and others to fine-tune wording and increase readability. 
That the information needed to achieve a high score and to be classified as 'very well informed' is included in the Commonwealth's Brief Guide indicates that the technical questions were not difficult and constituted what could be reasonably considered to be basic knowledge. The 'knowledge of compounding' question could be answered by any financially-literate person. Only the 'agepension payment-rate' question, which was not multiple-choice, called for knowledge that may not be generally known, but is nevertheless likely to be known by people nearing the pension threshold age or who have parents at or near age-pension age.

The survey was administered by post. In order to limit the cost of administration and to avoid the privacy problems arising when researchers attempt to use databases of names collected for other purposes, the 'unaddressed mail' householder delivery service provided by Australia Post was used. Under the conditions of this service, Australia Post will deliver an unaddressed letter to all or a specific number of street addresses or Post Office boxes as required for about 20 per cent of the cost of a normal letter delivery.

Two suburbs in Brisbane were chosen as the target population. In view of the evidence that the general level of knowledge of superannuation is very low, no attempt was made to select a random sample of the Australian population - the ING survey found, only a well-off minority were interested in the subject. Hence it was postulated that the highest levels of knowledge were to be found among the higher-educated and higher-income segments of the population. Thus, if testing found knowledge to be low among this group, it could be safely concluded that knowledge among the whole population is parlous. The two suburbs were Bardon and Chapel Hill, both (upper) middle-class western suburbs with high populations of tertiary-educated people. According to 2001 census data, almost 61 per cent of both Bardon's and Chapel Hill's population over 15 years of age held postsecondary qualifications of which 36.2 per cent and 34.7 per cent respectively were undergraduate degrees or above, compared with 46 per cent (with 17 per cent undergraduate or above) for the national population (Australian Bureau of Statistics, 2003).

The survey instrument together with an introductory letter and a reply-paid envelope was posted in mid-September 2003 and replies were received until early October. A total of 393 useable replies were received, an apparent response rate of eight per cent. The actual response rate is impossible to compute with unaddressed surveys because researchers cannot be sure all of the despatched survey packets were indeed delivered to householders. However, an eight per cent response rate in these circumstances is gratifying. Respondents reported the demographic characteristics as given in Table 1.

\section{Analytical approach}

The data were entered into a spreadsheet and the number of correct responses ascertained for each respondent. A comprehensive suite of descriptive statistics was computed. Then, OLS regression models were developed and estimated for 
the whole sample and separately for the two sexes and two subsets based on wealth. Other statistical models such as probit regression together with data transformations were estimated, but were rejected in favour of the simplicity and parsimony of OLS. OLS regression modelling is able to provide estimates of the signs and statistical significance of the independent variables that were, arguably, considered to be more important than the estimated values of the coefficients.

Table 1: Demographic Characteristics of Respondents

\begin{tabular}{llc}
\hline Characteristic & Male & $\begin{array}{c}\text { Respondents } \\
\text { (per cent of 393) }\end{array}$ \\
\hline Gender & Female & 58.8 \\
& $<39$ years & 41.2 \\
\hline Age & $40-54$ & 20.8 \\
& $55-69$ & 45.0 \\
& 70 and above & 31.8 \\
\hline Education & Secondary & 2.3 \\
& Trade/diploma & 16.3 \\
& Graduate & 13.0 \\
& Postgraduate & 35.1 \\
Income & $<\$ 30,000$ pa & 35.6 \\
& $\$ 30,000-\$ 50,000$ & 14.0 \\
& $\$ 50,000-\$ 70,000$ & 26.4 \\
& $\$ 70,000-\$ 100,000$ & 23.7 \\
& $>\$ 100,000$ & 16.0 \\
& $<\$ 500,000$ & 17.8 \\
\hline Wealth & $>\$ 500,000$ & 51.6 \\
& & 48.4 \\
\hline
\end{tabular}

\section{Results}

Descriptive Statistics

Table 2 explains the subject of each technical question and gives the percentage of respondents with the correct answer. It is apparent from the table that the bestknown information about superannuation is that superannuation funds are invested in the same assets as other financial investments but that the funds are quarantined in a separate taxation and investment structure ( 77.9 per cent correct) and, 
secondly, that the size of regular contributions is the most important determinant of the final lump-sum value (73.8 per cent correct), rather than earning rates, taxation or fees charged. Next well-known was the preservation age of 55 years for people born before 1 July 1960 (64.1 per cent correct).

Table 2: Percentage Correct for Each Technical Question

\begin{tabular}{lc}
\hline Question & $\begin{array}{c}\text { Correct Responses } \\
\text { (per cent of 393) }\end{array}$ \\
\hline How super differs from other investments & 77.9 \\
Most important determinant of size of lump sum & 73.8 \\
Preservation age & 64.1 \\
Current rate for super guarantee scheme & 59.0 \\
Contributions tax rate & 57.5 \\
Compassionate access to super & 57.0 \\
Earnings tax rate & 56.0 \\
Lump-sum benefits tax rate & 45.0 \\
Nature of undeducted contributions & 33.3 \\
Nature of allocated pension & 25.2 \\
Taxation of undeducted contributions & 22.9 \\
Number of sets of RBLs & 22.6 \\
Size of lump sum at retirement & 20.1 \\
Why allocated pensions counted against lump- & 18.1 \\
sum RBLs & \\
Size lump-sum vs pension RBLs & 17.0 \\
Age limit for super guarantee contributions & 15.5 \\
Time limit after working for super contributions & 12.0 \\
Size of age pension & 9.7 \\
\hline
\end{tabular}

There were four questions for which 56-59 per cent of the respondents knew the correct answers. These were:

- the current mandated percentage of 9 per cent of employees' pay which must be paid by employers into superannuation for their employees;

- the contributions taxation rate of these mandated contributions of 15 per cent;

- $\quad$ grounds for APRA to approve compassionate early access to superannuation;

- taxation rate of 15 per cent on superannuation funds' current earnings. 
In addition, 45 per cent of respondents knew lump-sum benefits from contributions made in the last 20 years are taxed at 15 per cent above a tax-free threshold.

Finally, two-thirds or more of the respondents did not know the answers to 10 of the 18 technical questions. Only one-third (33.3 per cent) knew the nature of undeducted contributions as contributions made by superannuation fund members from their after-tax funds. Thereafter, there were two groups totalling nine of the 18 questions for which only 20-25 per cent and 10-20 per cent of respondents gave correct answers.

The questions for which correct answers were known by 20-25 per cent of respondents were:

- the nature of an allocated pension in that benefit payments are flexible and may be re-set annually;

- undeducted contributions are tax-free on entry and exit with taxed earnings;

- retirees have one set of RBLs even though they might have funds with several providers;

- the nature of compounding of returns so that about $\$ 400,000$ may be needed at retirement to provide $\$ 30,000$ annual income for 25 years.

- In addition, the questions for which fewer than 20 per cent of respondents gave the correct answers were:

- the reason allocated pensions are counted against lump-sum RBLs (18.1 per cent correct);

- the relative sizes of the pension and lump-sum RBLs (17.0 per cent correct);

- the age to which compulsory superannuation contributions are mandated (15.5 per cent correct);

- the period of two years after working in which a person aged less than 65 years may make superannuation contributions (12.0 per cent correct);

- the current amounts of either the single or couple Commonwealth age pension (9.7 per cent correct).

Table 3: Scores Gained by Respondents

\begin{tabular}{lcc}
\hline Score class & Score range & $\begin{array}{c}\text { Respondents in } \\
\text { each score class } \\
\text { (per cent) }\end{array}$ \\
\hline Very well informed & $15-18$ & 3.6 \\
Quite well informed & $10-14$ & 18.1 \\
Not very well informed & $6-9$ & 38.9 \\
Not at all informed & $0-5$ & 39.4 \\
\hline
\end{tabular}


Table 3 provides the percentages of respondents who scored in each of four classes ranging from very well informed to not at all informed. From this table, it is apparent that only 21.7 per cent of respondents scored a 'pass' if the hurdle is set at the traditional 50 per cent mark. The mean score was 6.8 , the median 7 and the modal score 5. Table 4 gives respondents' reported perceptions of their own knowledge by the same classification and contrasts these with their achieved ranges of test scores.

\section{Table 4: Perceived Knowledge and Achieved Scores}

\begin{tabular}{lcc}
\hline Score class & $\begin{array}{c}\text { Respondents' own } \\
\text { perceptions of } \\
\text { knowledge } \\
\text { (per cent) }\end{array}$ & $\begin{array}{c}\text { Achieved scores } \\
\text { by respondents in } \\
\text { each class }\end{array}$ \\
\hline Very well informed & 4.3 & $5-17$ \\
Quite well informed & 31.8 & $2-18$ \\
Not very well informed & 53.9 & $0-14$ \\
Not at all informed & 10.0 & $0-8$ \\
\hline
\end{tabular}

In all, 29 respondents under-estimated their own knowledge of superannuation - eight 'quite well informed' people achieved 'very well informed' scores, 17 'not very well informed' achieved 'quite well informed' scores and four 'not at all informed' people achieved higher scores than this category. On the other hand, 187 respondents over-estimated their knowledge as measured by this test. Twelve respondents who rated themselves 'very well informed' scored one, two or three classes below this category, 70 'quite well informed' respondents scored either one or two classes below and 105 'not very well informed' respondents scored in the 'not at all informed' class. Testing of the demographic characteristics of this subset of overconfident respondents showed that there was no characteristic which differentiated this group from the rest of the sample. In other words, people overconfident of their superannuation knowledge came from all the groups represented - both male and female, from all age groups, all education levels, all incomes and all wealth classes.

\section{Regression modelling}

OLS regression modelling was used to test the proposition that the score gained by each respondent as the dependent variable was influenced by that person's knowledge-perception (SPK) variable, gender, age, education, occupation, income and wealth. Table 5 gives the values each variable could take and the researchers' a priori estimates of signs. Most variables were postulated to be positive on the basis that the older the respondent was and the higher the education, skill level, income and wealth, the better would be the knowledge of the superannuation 
system. In contrast, the SPK variable was likely to be negative as it was defined so that the high values indicated less SPK. The gender variable was thought to be either positive or negative, but was more likely to be positive as anecdotal evidence and previous research (ASFA, 2002; Beal and Delpachitra, 2003) have suggested that males are more likely to be interested in retirement-income issues.

Table 5: Definition of Variables and Expected Signs

\begin{tabular}{|c|c|c|}
\hline Variable & Values & $\begin{array}{c}\text { A priori } \\
\text { signs }\end{array}$ \\
\hline SPK & $\begin{array}{l}1=\text { very well informed to } \\
4=\text { not at all informed }\end{array}$ & - \\
\hline Gender & $1=$ male $; 0=$ female & + or - \\
\hline Age & $\begin{array}{l}1=\text { age } 22-30 \text { years to } \\
5=70 \text { years and above }\end{array}$ & + \\
\hline Education & $\begin{array}{l}1=\text { mid-secondary or less to } \\
5=\text { postgraduate }\end{array}$ & + \\
\hline Occupation & $\begin{array}{l}1=\text { semi-skilled to } \\
3=\text { professional } / \text { managerial }\end{array}$ & + \\
\hline Income & $\begin{array}{l}1=\text { less than } \$ 20,000 \text { to } \\
8=\text { more than } \$ 150,000\end{array}$ & + \\
\hline Wealth & $\begin{array}{l}1=\text { less than } \$ 50,000 \text { to } \\
5=\text { more than } \$ 500,000\end{array}$ & + \\
\hline
\end{tabular}

Table 6: Results of Regression Analysis

\begin{tabular}{lll}
\hline Variable & $\begin{array}{l}\text { Estimated } \\
\text { Coefficient }\end{array}$ & t-ratio \\
\hline SPK & -2.37 & $-11.3^{*}$ \\
Gender & 1.09 & $3.43^{*}$ \\
Age & 0.60 & $3.41^{*}$ \\
Education & 0.27 & $2.08^{*}$ \\
Occupation & -0.17 & -0.69 \\
Income & -0.06 & -0.74 \\
Wealth & 0.45 & $3.37^{*}$ \\
\hline
\end{tabular}

* statistically significant at the 0.05 level 
Table 6 gives the results of the regression model, using the whole sample, with the test score as the dependent variable. As can be seen from the table, the SPK variable, gender, age, education and wealth were found to be statistically significant determinants (at the 0.05 level) of the attained knowledge scores. The adjusted $\mathrm{R}^{2}$ for the estimation was 0.41 . The residuals were checked for normality with the Jarque-Bera test (4.189 with two degrees of freedom.)

Further models were estimated. The data were divided into two subsets on the basis of, firstly, gender and, secondly, wealth with the hurdle set at $\$ 500,000$. Table 7 gives the estimated coefficients, the t-scores and the adjusted $\mathrm{R}^{2}$ values for each model. The adjusted $\mathrm{R}^{2}$ values for the five estimated models show that 30-46 per cent of the variation in the dependent variable is explained by variation in the independent variables in the respective models. The Jarque-Bera normality tests indicated the residuals were normally distributed in all four cases.

Table 7: Results of Regression Analysis

\begin{tabular}{lllll}
\hline Variable & $\begin{array}{l}\text { Estimated } \\
\text { Coefficient }\end{array}$ & t-ratio & $\begin{array}{l}\text { Estimated } \\
\text { Coefficient }\end{array}$ & t-ratio \\
\hline Males & & & Females \\
SPK & -2.08 & $-7.34^{*}$ & -2.94 & $-10.18^{*}$ \\
Age & 0.57 & $2.34^{*}$ & 0.46 & $1.98^{*}$ \\
Education & 0.54 & $2.65^{*}$ & 0.01 & 0.07 \\
Occupation & -0.24 & -0.64 & -0.12 & -0.41 \\
Income & -0.22 & -1.67 & 0.16 & 1.32 \\
Wealth & 0.71 & $3.65^{*}$ & 0.09 & 0.54 \\
$\mathrm{R}^{2}=0.30$ & & & $\mathrm{R}^{2}=0.46$ & \\
Wealth $<\mathbf{\$ 0 0 , 0 0 0}$ & & $\mathbf{W e a l t h}>\mathbf{\$ 5 0 0 , 0 0 0}$ \\
SPK & -2.38 & $-8.62^{*}$ & -2.43 & $-7.45^{*}$ \\
Gender & 0.89 & $2.13^{*}$ & 1.12 & $2.24^{*}$ \\
Age & 0.67 & $3.36^{*}$ & 0.65 & $2.12^{*}$ \\
Education & 0.17 & 0.92 & 0.39 & $1.98^{*}$ \\
Occupation & -0.14 & -0.42 & -0.02 & -0.05 \\
Income & 0.04 & 0.29 & -0.06 & -0.48 \\
$\mathrm{R}^{2}=0.35$ & & & $\mathrm{R}^{2}=0.31$ & \\
\hline
\end{tabular}

* statistically significant at the 0.05 level. 
When comparing the results of the subset models with the full-dataset model, it can be seen that the significant variables remain much the same among all models, the only exceptions being that education and wealth are shown not to be statistically significant determinants of score for the women in the sample and education level is not significant for the less wealthy cohort of the group.

\section{Discussion and Conclusion}

These research findings highlight the parlous state of knowledge of the Australian community about their government-mandated superannuation system which has been designed to deliver to them their retirement incomes. The findings complement the results of research conducted in the USA and Canada and highlight the relatively superior knowledge among older, higher-educated and more wealthy people.

The research was not conducted among the general population, but was purposely directed towards a higher-educated, higher-wealth, mainly professional and managerial cohort, on the basis that these people have the highest probability of having an active interest in and knowledge of superannuation (as shown by the ING survey). They may also be familiar with the political debate regarding choice and be aware of the personal implications should unlimited choice be granted.

The results, therefore, were deliberately biased towards apparent greater knowledge of superannuation. In addition, while nearly 400 responses is a useful number of responses, the response rate was low and it is to be expected the scores of the non-respondents would have been worse than those of the respondents. Indeed, the researchers noted the late respondents almost uniformly scored poorly. Thus, the results are undoubtedly biased on at least two fronts - the higheducation, high-wealth basis and the low response rate. With 70.7 per cent of respondents reporting having gained either undergraduate degrees or postgraduate qualifications as their highest level of education, it would be reasonably difficult to find a group of the general public with higher education levels. Yet, even with this background, no more than 21.7 per cent of the sampled respondents could score a traditional more than 50 per cent pass mark.

That a majority knew that superannuation funds are invested in the 'ordinaryinvestment' asset classes and not in special areas, that the size of regular contributions is more important for lump-sum aggregation than earning rates, fees and taxes (even though these too are important), and that the 'standard' (born before 1 July 1960) preservation age is 55 years is comforting, but these gems of knowledge must be supported by much more understanding before an individual could be considered to be superannuation-literate. A smaller majority of 56-59 per cent of respondents knew the current mandated employer-contribution rate of nine per cent, the grounds for APRA to grant compassionate access to superannuation and a number of the pertinent tax rates. That 41 per cent did not select 'nine per cent' as the employer contribution seems, by itself, to indicate a blithe indifference to this important social issue. In light of this result, if nothing else, the result of 57 per cent selecting the correct answer to the compassionate grounds question was 
somewhat surprising, but perhaps this issue is talked about more often among groups of friends and workers. Similarly, perhaps the ubiquitous 15 per cent tax rates for various cash flows to and from the superannuation framework are discussed among friends, or perhaps, for some, the correct answers were just lucky guesses.

Most important are the issues about which the respondents knew little. Only 33.3 per cent knew the nature of undeducted contributions, and 22.9 per cent knew undeducted contributions are tax-free on entry to and exit from the superannuation system with taxed earnings. This knowledge is vital to the formulation of appropriate savings and investment strategies. This suggests there is little active discretionary saving being practised through the superannuation system, except perhaps through salary-sacrifice. For many people in the middle-aged cohorts, who are without lifetime compulsory superannuation support, this suggests their superannuation savings will not be sufficient to support comfortable retirements. An alternative explanation is that people are not conversant with the correct terminology. For example, some funds refer in documentation to 'member contributions' without defining exactly the tax-status of these contributions which could be before-tax (that is, 'salary sacrifice' or tax-deductible non-employer supported contributions) or after-tax (that is, 'undeducted contributions'). Keeping track of the tax status of members' own contributions underlies the effective management of RBLs.

With regard to allocated pensions, 25.2 per cent knew that the benefit payments are flexible and may be re-set annually but only 18.1 per cent knew the reason these pensions are counted against lump-sum RBLs. Both these characteristics are important knowledge for people involved in retirement planning, whether they be on the verge of retirement or many years away from that event. Similarly, only 22.6 per cent of respondents knew that they have only one set of RBLs regardless of the number of different superannuation-fund accounts, and 17 per cent knew that the pension RBL is about double the lumpsum RBL. Again, this is vital knowledge for active retirement planners.

Two general superannuation questions were also poorly known. Only 15.5 per cent knew that employers must make contributions for employees until age 70 years and 12.0 per cent knew that funds may accept personal contributions from members under age 65 years at any time within two years of their last full- or parttime gainful employment. Additionally, only 20.1 per cent were able to nominate $\$ 400,000$ as a lump-sum which may provide $\$ 30,000$ pa for 25 years in retirement. Some of the more financially-literate people wrote next to the question, 'What is the discount rate?' However, part of the point of the question was that people planning their retirement incomes must think about and select an appropriate discount rate which they believe their funds will be able to earn. Moreover, for the answer ' $\$ 700,000$ ', which was given by 53 per cent of respondents, to be correct, the retirement funds would have to earn only 0.5 per cent pa on average for the whole 25 years. This is unlikely!

Finally, respondents' knowledge of the age-pension payment rate, currently available when self-funding fails, was very poor. At the same time, there is a 
great deal of evidence that Australians of middle age and nearing retirement have not saved enough and will be relying on either full or part-pensions for their retirement incomes. Only 9.7 per cent of respondents were able to quote either the single person's or couple's maximum annual benefit rate to the nearest thousand dollars. The average of nominated amounts was about $\$ 16,000$ for single people and $\$ 23,000$ for couples. These amounts are both about $\$ 4,000$ pa too high at the current time. The ranges of amounts nominated also highlight the general lack of knowledge of this issue: $\$ 3,000$ to $\$ 70,000$ for single people and $\$ 8,000$ to $\$ 50,000$ for couples. Perhaps over-optimism about the age-pension maximum benefit is part of the explanation for individuals' insouciance about their superannuation planning.

Another issue of concern is over-confidence of knowledge of the superannuation system. Even though only 21.7 per cent of respondents could achieve a 'pass' mark, 36.1 per cent thought they were at least 'quite well informed'. Some of these people achieved scores as low as two, three and four. One self-styled 'very well informed' person achieved a score of five on this test, which included questions only on basic characteristics. None of the questions concerned the more difficult area of strategy, which financially-literate retirement planners must also master if they are to make best use of their savings.

The most important policy issue from these research results is that more money must be spent by the Commonwealth Government on education of the community. Without having the requisite knowledge, people are inclined to ignore superannuation as a savings vehicle. Additionally, they certainly are unable to make informed choices about contributing through salary-sacrifice or after-tax funds given the constraints of RBLs and taxation issues.

First, money must be spent on trying to raise awareness and improve the connection people have with their superannuation savings. At the moment, people apparently feel at the remove, and that these funds are not theirs to manage. Second, money must be spent on improving the community's knowledge of how the system works. Television advertising designed to reach to the whole community and to advance knowledge in small incremental steps would appear to be a better use of funds than the production and distribution of more comprehensive 'manuals'. The private sector has used these methods to advantage, and there would appear to be no reason that superannuation could not be 'sold' in the same manner. The findings of this research may serve as a starting point for the design of such a program.

\section{References}

Australian Bureau of Statistics (2003), Usual Resident's Profiles, Postcodes 4065 and 4069, Canberra Catalogue 2004.0.

Association of Superannuation Funds of Australia (2002), 'Report on Workforce Perceptions and Attitudes to Superannuation' [Online], Available: http://www.asfa.asn.au/policy/ANOP\%20Aug\%202002.pdf, [Accessed 23 February 2004] 
Beal, D. and S. Delpachitra (2003), 'Defying the Clock - A Profile of Australians who Ignore Retirement Planning', Journal of Economic and Social Policy 7(2):1-14.

Brown, K., G. Gallery and N. Gallery (2002), 'Informed Superannuation Choice: Constraints and Policy Resolutions', Economic Analysis and Policy 32(1):71-90.

Chan, S. and A. Stevens (2003), 'What You Don't Know Can't Help You: Pension Knowledge and Retirement Decision Making', NBER Working Paper 10185, NBER, Cambridge, MA.

Coonan, H. (2002), A Brief Guide to Superannuation, Commonwealth Treasury, Canberra.

Drew, M. and J. Stanford (2002), 'The Economics of Choice of Superannuation Fund', Accounting, Accountability and Performance 8(1):1-20.

Gallery, G. and N. Gallery (2003), 'Inadequacies and Inconsistencies in Superannuation Fund Financial Disclosure: The Need for a Principles-Based Approach', Australian Economic Review 36(1):89-97.

Gustman, A. and T. Steinmeier (2001), 'Imperfect Knowledge, Retirement and Saving', NBER Working Paper 8406, NBER, Cambridge, MA.

Gustman, A. and T. Steinmeier (1999), 'What People Don't Know about their Pensions and Social Security: An Analysis using Linked Data from the Health and Retirement Study', NBER Working Paper 7368, NBER, Cambridge, MA.

Howe, B. (Minister for Social Security) (1989), Better Incomes: Retirement Incomes Policy into the Next Century, AGPS, Canberra.

Luchak, A. and M. Gunderson (2000), 'What do Employees Know about their Pension Plan?', Industrial Relations 39(4):646-670.

Mitchell, O. (1988), 'Worker Knowledge of Pension Provisions', Journal of Labor Economics 6(1):21-39.

McKeown, W. (2003), 'Superannuation', Chapter 12 in D. Beal and W. McKeown, Personal Finance, Wiley, Brisbane.

Senate (1998), Choice of Fund, 28th Report of the Senate Select Committee on Superannuation, Senate, Parliament of Australia, Canberra.

The authors are indebted to two anonymous referees for their helpful comments 